\title{
Antifungal treatments in artificial incubation of crayfish eggs (Pacifastacus leniusculus, Astacidae): Searching for alternatives to formaldehyde
}

\author{
J.M. Carral ${ }^{(1)}$, A. González ${ }^{(1)}$, J.D. Celada ${ }^{(1)}$, M. Sáez-Royuela ${ }^{(1)}$, \\ P.M. Melendre ${ }^{(1)}$, R. González ${ }^{(1)}$, V. García ${ }^{(1)}$ \\ Received September 29, 2009 / Reçu le 29 septembre 2009 \\ Revised February 3rd, 2010 / Révisé le 3 février 2010 \\ Accepted February 6, 2010 / Accepté le 6 février 2010
}

Key-words: antifungal treatment, artificial incubation, astacid crayfish

\section{ABSTRACT}

Considering the concerns about the safety of the use of formaldehyde as antifungal agent, the effects of three alternative chemicals (potassium sorbate, copper hydroxide and magnesium chloride) were tested in the artificial incubation of signal crayfish (Pacifastacus leniusculus) eggs. Eight treatments were performed during 15 min every other day: formaldehyde at $3000 \mathrm{ppm}$ (control), potassium sorbate at 5000 and $10000 \mathrm{ppm}$, copper hydroxide at 40, 60, 80 and $200 \mathrm{ppm}$, and magnesium chloride at $10000 \mathrm{ppm}$. Eggs were incubated in a flow through system at a density of 20 eggs $\mathrm{cm}^{-2}$. After 61 days of incubation, the highest efficiencies were obtained with $200 \mathrm{ppm}$ of copper hydroxide $(77.6 \%$ of survivors to stage 2) with no significant differences from the control (74.3\%). Lower concentrations of copper hydroxide resulted in high egg mortality whereas potassium sorbate and magnesium chloride were ineffective to avoid fungal growth and total egg mortality took place. From the obtained results, copper hydroxide baths at 200 ppm could be considered as a good alternative to formaldehyde.

RÉSUMÉ

Traitements antifongiques lors d'incubations artificielles d'œufs d'écrevisse (Pacifastacus leniusculus, Astacidae) : recherche d'alternatives au formaldéhyde

Mots-clés:
traitement
antifongique,
incubation
artificielle,
écrevisse
astacidé

\section{Mots-clés :} antifongique, incubation écrevisse astacide 
fongique et une mortalité totale des œufs intervenait. À partir des résultats obtenus, des bains d'hydroxyde de cuivre à 200 ppm peuvent être considérés comme une bonne alternative au formaldéhyde.

\section{INTRODUCTION}

In astacid crayfish, advances in artificial incubation techniques (Al) provide reliable options for its application under culture conditions (see review by González et al., 2009). Depending on stripping time and temperature, artificial incubation covers long periods, over 100 days (Pérez et al., 1998), during which nonviable eggs can be invaded by fungi, usually Saprolegnia spp. and other Oomycetes (Edgerton et al., 2002). Their hyphae can spread to the surrounding healthy ones (Celada et al., 2004; Melendre et al., 2006; Sáez-Royuela et al., 2009) causing an important decrease of efficiency rates. Periodical removal of dead eggs has shown positive effect on the hatching rate (Carral et al., 2004; Policar et al., 2006) but it is laborious and manipulation can cause damages in healthy ones, giving rise to new losses (Sáez-Royuela et al., 2009). Thus, the use of antifungal treatments would be advisable, and several studies have been addressed to find effective chemicals.

For many years malachite green has been the most effective fungicide used in aquaculture but since 1991 and 1997 is not permitted for aquaculture in USA (Schereier et al., 1996) and EU (Celada et al., 2004) respectively, because of its teratogenic and carcinogenic effects (Andersen et al., 2006; Sapkota et al., 2008). After a series of trials testing chemicals used in other aquatic species, Celada et al. (2004) and Melendre et al. (2006) reported formaldehyde as the most effective antifungal. Although formaldehyde is approved for use in fish culture in USA and EU, there is concern about user safety because of its suspected carcinogenicity and its potential adverse effects on the aquatic environment (Arndt et al., 2001; Gieseker et al., 2006).

Considering the convenience of antifungal agents alternative to formaldehyde, the aim of this study was to obtain data on the possible effectiveness of other chemicals. Three were selected: potassium sorbate (E202) is used to inhibit molds and yeasts in many foods for food preservation and extension of shelf-life (Dorko et al., 1997), copper hydroxide $\left(\mathrm{Cu}(\mathrm{OH})_{2}\right)$ is commonly used to prevent some fungal diseases of fruit and vegetable crops, and magnesium chloride $\left(\mathrm{MgCl}_{2}\right)$ was proposed by Rantamäki et al. (1992) to prevent transmission of the crayfish plague fungus (Aphanomyces astaci).

\section{MATERIALS AND METHODS}

Eggs from 70 berried Pacifastacus leniusculus females from a crayfish farm were detached in the laboratory by sliding blunt forceps smoothly from the base to the tip of the pleopods. Prior to artificial incubation, embryonic phases were identified following Celada et al. (1985, 1987 ) being at phase IX (embryo with naupliar appendages).

A total of 6400 eggs were pooled and artificially incubated in the experimental devices described by Carral et al. (1992) and Sáez-Royuela et al. (2009) up to stage 2 juvenile production. Artesian well water was supplied in open system at a flow rate of $0.5 \mathrm{~L} \cdot \mathrm{min}^{-1}$ $\left(12.5 \mathrm{~mL} \cdot \mathrm{cm}^{-2} \cdot \mathrm{min}^{-1}\right)$. The parameters of incoming water quality were: $\mathrm{pH} 7.9$, hardness $5.2^{\circ} \mathrm{dH}$ (calcium: $32.3 \mathrm{mg} \cdot \mathrm{L}^{-1}$ ), dissolved oxygen about $8 \mathrm{mg} \cdot \mathrm{L}^{-1}$, nitrite $<0.015 \mathrm{mg} \cdot \mathrm{L}^{-1}$, ammonium $<0.02 \mathrm{mg} \cdot \mathrm{L}^{-1}$, total dissolved solids $110.5 \mathrm{mg} \cdot \mathrm{L}^{-1}$, and total suspended solids $<0.5 \mathrm{mg} \cdot \mathrm{L}^{-1}$. Temperature was $10 \pm 1{ }^{\circ} \mathrm{C}$ until eggs reached the eye stage (phase XIII). Thereafter, it was raised to $15.5 \pm 1{ }^{\circ} \mathrm{C}$ up to final stage 2 juvenile production.

Chemicals used were formaldehyde (Proquiman S.L.) at $3000 \mathrm{ppm}$, magnesium chloride $\left(\mathrm{MgCl}_{2}\right.$, Sigma-Aldrich) at $10000 \mathrm{ppm}$, potasium sorbate (E202, Coralim Aditivos) at 5000 and 10000 ppm, and copper hydroxide $\left(\mathrm{Cu}(\mathrm{OH})_{2}\right.$, Funguran-OH 50 WP, Nufarm España S.A.) 


\section{Table I}

Survival rates in artificial incubation receiving eight antifungal treatments. Values followed by differing letters were significantly different $(P<0.05)$ from the others in the same column. SEM = standard error of mean.

\section{Tableau I}

Taux de survie en incubation artificielle selon huit traitements antifongiques. Les valeurs suivies de différentes lettres sont significativement différentes $(P<0,05)$ des autres de la même colonne. SEM = erreurstandard de la moyenne.

\begin{tabular}{|l|l|c|c|c|}
\hline Chemical agent & $\begin{array}{c}\text { Concentration } \\
(\mathrm{ppm})\end{array}$ & Application form & $\begin{array}{c}\text { Stage 1 } \\
(\% \pm \text { SEM) }\end{array}$ & $\begin{array}{c}\text { Stage 2 } \\
(\% \pm \text { SEM })\end{array}$ \\
\hline Formaldehyde (control) & 3000 & Peristaltic pumps & $83.7 \pm 0.4^{\mathrm{a}}$ & $74.3 \pm 2.8^{\mathrm{a}}$ \\
\hline \multirow{3}{*}{ Potassium sorbate } & 5000 & Peristaltic pumps & 0 & 0 \\
\hline \multirow{3}{*}{ Copper hydroxide } & 10000 & Static baths & 0 & 0 \\
& 60 & & $10.3 \pm 3.1^{\mathrm{b}}$ & $2.5 \pm 1.5^{\mathrm{b}}$ \\
& 80 & & $86.2 \pm 1.5^{\mathrm{a}}$ & $77.6 \pm 5.6^{\mathrm{a}}$ \\
\hline Magnesium chloride & 200 & & 0 & 0 \\
\hline
\end{tabular}

at $40,60,80$ and 200 ppm. Treatments were administered during 15 min every other day up to the beginning of hatchings. Solutions of formaldehyde, potasium sorbate and magnesium chloride were discharged to the incoming water flow using peristaltic pumps. Because its low solubility in water, copper hydroxide treatments were performed in static baths.

Each treatment was performed by quadruplicate at an egg density of $20 \mathrm{~cm}^{-2}$ (one complete layer, eggs contacting to others). Throughout incubation eggs were daily checked by careful ocular inspection and any presence of fungal growth was noted. Dead eggs were not removed. The number of stage 1 (after hatching) and stage 2 (after first moult) juveniles was quantified. Collection of stage 2 juveniles was carried out daily following the recommendation of Melendre et al. (2007), because final survival is reduced the longer they remain in the incubators. Survival rates were calculated as the percentage of juveniles from the initial number of eggs.

Prior statistical analysis arc-sine transformation of percentages was made. Results were examined by analysis of variance (one-way ANOVA) using the SPSS 16.0 computer program (SPSS Inc., Chicago, USA). Mean comparison was tested using the Duncan's test. The significance level was $P<0.05$.

\section{RESULTS}

Artificial incubation lasted for 61 days. Hatchings began on day 43, stage 2 juveniles were obtained from day 51 and the first moult period lasted for 10 days.

Survival rates in each treatment are presented in Table I. The highest survival rate to stage 2 (77.6\%) was obtained with copper hydroxide at 200 ppm for 15 minutes every other day, with no significant difference from the formaldehyde control (74.3\%). In both cases no fungal growth was observed. However, on eggs treated with copper hydroxide at 40 and $60 \mathrm{ppm}$ fungi were observed from day 14 onwards, whereas at $80 \mathrm{ppm}$ from day 19. In the later case, a low production of stage 2 juveniles was obtained (2.5\%).

Earlier fungal growth was observed in eggs treated with potassium sorbate and magnesium chloride, from day 5 onwards, affecting all the eggs and causing total mortality.

\section{DISCUSSION}

Copper hydroxide is a widely used fungicide-bactericide approved for both organic and conventional agricultural production of vegetable crops for control of diseases (Rice et al., 2007). 
Although there are no references of its use in aquatic species it was the only one, among the chemicals tested as alternative to formaldehyde, effective to prevent fungal growth on crayfish eggs. As it has been proved with other antifungal tested (Celada et al., 2004; Melendre et al., 2006; Policar et al., 2006; Sáez-Royuela et al., 2009), artificial incubation of astacid crayfish eggs calls for higher concentrations than those recommended for other species. In the case of copper hydroxide, the lower concentrations tested did not avoid the presence of fungus which were observed after 14-19 days of incubation, resulting in poor survival to stage 2 juveniles (2.5\% at 80 ppm) or total mortality (at 40 and 60 ppm). However at 200 ppm, juvenile production was high $(77.6 \%)$ and similar to the obtained with formaldehyde.

Because their low water solubility, copper complexes, including $\mathrm{Cu}(\mathrm{OH})_{2}$, tend to precipitate and thus administration by means of peristaltic pumps does not guarantee the concentration received on eggs, as Melendre et al. (2006) pointed out for the copper sulphate. Thus, the application of these chemicals should be restricted to static baths leading to additional man work throughout the Al period.

Considering that Saprolegnia spp. and the genus Aphanomyces belong to the same family (Diéguez-Uribeondo et al., 2006), magnesium chloride was tested. The concentration used was the proposed by Rantamäki et al. (1992) as effective to reduce the sporulation process of A. astaci, but it did not prevent the fungal growth on eggs and total mortality was registered. The same occurs with potassium sorbate (E202) widely used to inhibit molds and yeasts in many foods, even when it was applied at higher concentrations. Considering this, both agents should be rejected as antifungal in astacid artificial incubation, at least at the concentrations tested.

Other antifungal agents effective on artificial incubation of crayfish eggs, such as formaldehyde, have also disinfection effects allowing producing specific virus-free juveniles (Edgerton and Owens, 1997) or faster growth juveniles (González et al., 2009). Considering the potent biocidal properties of cooper, alone or in complexes, which determine their wide current usages as antibacterial, antifungal and antiviral (Borkow and Gabbay, 2009), it would be expected a similar performance.

To sum up, copper hydroxide at $200 \mathrm{ppm}$ administered in 15 min static baths every other day can be considered as effective alternative to formaldehyde. Further research on accurate concentration of this copper compound and others commonly used in aquatic species, such as copper sulphate, should be developed.

\section{ACKNOWLEDGEMENTS}

Funding of this study was the Plan Nacional de I+D+i, Ministerio de Eduación y Ciencia, Spain, Research Project AGL2005-01127. We should also like to thank the Quiñón S.A. crayfish farm for their collaboration.

\section{REFERENCES}

Andersen W.C., Turnipseed S.B. and Roybal J.E., 2006. Quantitative and confirmatory analyses of malachite green and leucomalachite green residues in fish and shrimp. J. Agric. Food Chem., 54, 13, 4517-4523.

Arndt R.E., Wagner E.J. and Routledge M.D., 2001. Reducing or withholding hydrogen peroxide treatment during a critical stage of rainbow trout development: effects on eyed eggs, hatch, deformities, and fungal control. N. Am. J. Aquac., 63, 161-166.

Borkow G. and Gabbay J., 2009. Copper: an ancient remedy returning to fight microbial, fungal and viral infections. Curr. Chem. Biol., 3, 3, 272-278.

Carral J.M., Celada J.D., González J., Gaudioso V.R., Fernández R. and López-Baissón C., 1992. Artificial incubation of crayfish eggs (Pacifastacus leniusculus Dana) from early stages of embryonic development. Aquaculture, 105, 261-269. 
Carral J.M., Pérez J.R., Celada J.D., Sáez-Royuela M., Melendre P.M. and Aguilera A., 2004. Effects of dead egg removal frequency on stage 2 juvenile production in artificial incubation of Austropotamobius pallipes Lereboullet. Bull. Fr. Pêche Piscic., 372-373, 425-430.

Celada J.D., Gaudioso V.R., Paz P. and Fernández R., 1985. Identification et chronologie des phases de developpement des œufs de l'écrevisse (Pacifastacus leniusculus Dana) par observation directe. Piscic. Fr. , 82, 5-8.

Celada J.D., Paz P., Gaudioso V.R. and Fernández R., 1987. Embryonic development of the freshwater crayfish (Pacifastacus leniusculus Dana): a scanning electron microscopic study. Anat. Rec., 219, 304-310.

Celada J.D., Carral J.M., Sáez-Royuela M., Melendre P.M. and Aguilera A., 2004. Effects of different antifungal treatments on artificial incubation of the astacid crayfish (Pacifastacus leniusculus Dana) eggs. Aquaculture, 239, 249-259.

Diéguez-Uribeondo J., Cerenius L., Dyková I., Gelder S.R., Hentonnen P., Jiravanichpaisal P., Lom J. and Söderhäll K., 2006. Pathogens, parasites and ectocommensals. In: Souty-Grosset C., Holdich D.M., Noel P.Y., Reynolds J.D. and Haffner P. (eds.), Atlas of Crayfish in Europe, Publications Scientifiques du Muséum National d'Histoire Naturelle, 64, Paris, 131-149.

Dorko C.L., Ford G.T. Jr., Baggett M.S., Behling A.R. and Carman H.E., 1997. Sorbic acid, In: Kirk-Othmer Encyclopedia of Chemical Technology, 22, Wiley InterScience, 571-590.

Edgerton B.F. and Owens L., 1997. Age at first infection of Cherax quadricarinatus by Cherax quadricarinatus bacilliform virus and Cherax Giardivirus-like virus, and production of putative virus-free crayfish. Aquaculture, 152, 1-12.

Edgerton B.F., Evans L.H., Stephens F.J. and Overstreet R.M., 2002. Synopsis of freshwater crayfish diseases and commensal organisms. Aquaculture, 206, 57-135.

Gieseker C.M., Serfling S.G. and Reimschuessel R., 2006. Formalin treatment to reduce mortality associated with Saprolegnia parasitica in rainbow trout, Oncorhynchus mykiss. Aquaculture, 253, 120-129.

González R., Celada J.D., García V., González A., Carral J.M. and Sáez-Royuela M., 2009. The artificial incubation of crayfish eggs: review and report from an experiment concerning the effects of offspring origin (maternal or artificial incubation) on the survival and growth of juvenile crayfish (Pacifastacus leniusculus, Astacidae). Rev. Fish. Biol. Fisheries, 19, 167-176.

Melendre P.M., Celada J.D., Carral J.M., Sáez-Royuela M. and Aguilera A., 2006. Effectiveness of antifungal treatments during artificial incubation of the signal crayfish eggs (Pacifastacus leniusculus Dana. Astacidae). Aquaculture, 257, 257-265.

Melendre P.M., Celada J.D., Carral J.M., Sáez-Royuela M. and Aguilera A., 2007. Effects of stage 2 juvenile removal frequency on final survival rates in artificial incubation of crayfish eggs (Pacifastacus leniusculus Dana. Astacidae). J. Shellfish Res., 26, 1, 201-203.

Pérez J.R., Carral J.M., Celada J.D., Sáez-Royuela M., Muñoz C. and Antolín J.I., 1998. Effects of stripping time on the success of the artificial incubation of freshwater crayfish, Austropotamobius pallipes (Lereboullet), eggs. Aquac. Res., 29, 389-395.

Policar T., Kozák P. and Martín J., 2006. Effects of egg bath and daily removal of dead eggs on hatching success and production of stage 2 juveniles during artificial incubation in noble crayfish (Astacus astacus L.). Bull. Fr. Pêche Piscic., 380-381, 1197-1206.

Rantamäki J., Cerenius L. and Söderhäll K., 1992. Prevention of transmission of the crayfish plague fungus (Aphanomyces astaci) to the crayfish Astacus astacus by treatment with $\mathrm{MgCl}_{2}$. Aquaculture, 104, 11-18.

Rice P.J., Harman-Fetcho J.A., Heighton L.P., McConnell L.L., Sadeghi A.M. and Hapeman C.J., 2007. Environmental fate and ecological impact of copper hydroxide: Use of management practices to reduce the transport of copper hydroxide in runoff from vegetable production. American Chemical Society Symposium, 947, 230-244.

Sáez-Royuela M., Melendre P.M., Celada J.D., Carral J.M., González A., González R. and García V., 2009. Possibilities of artificial incubation of signal crayfish (Pacifastacus leniusculus Dana) eggs at high densities and reduced flow rate using formaldehyde as antifungal treatment. Aquaculture, 288, 65-68.

Sapkota A., Sapkota A.R., Kucharski M., Burke J., McKenzie S., Walker P. and Lawrence R., 2008. Aquaculture practices and potential human health risks: Current knowledge and future priorities. Env. Int., 34, 8, 1215-1226.

Schereier T.M., Rach J.J. and Howe G.E., 1996. Efficacy of formalin, hydrogen peroxide and sodium chloride on fungal infected rainbow trout eggs. Aquaculture, 140, 323-331. 